\title{
GENETIC Diversity in some Introduced Cassava Genotypes via Simple Sequence Repeat Markers (SSR)
} T.M.Salim ${ }^{1}$, H.S.Baiea ${ }^{1}$, M.M.M.Bekhit ${ }^{1}$, M.S.Abdel-Sabour ${ }^{1}$ and M.M.Elnagar $^{2}$ ${ }^{1}$ Genetics and Genetics Engineering Dept., Faculty of Agriculture, Benha Univ., Benha, Egypt ${ }^{2}$ Horticulture Dept., Faculty of Agriculture, Benha Univ., Benha, Egypt E-Mail: tamer.salem@fagr.bu.edu.eg

\begin{abstract}
The objective of this study was to characterize morphologically and molecularly genetic diversity of three important cassava genotypes (Manihot esculenta Crantz). Three Introduced cassava genotypes were utilized as a part of the present study. These genotypes named American, Brazilian, and Indonesian. These plants procured name as per its unique area. Morphological appraisal showed a few contrasts between the three genotypes. Plant leaf hues demonstrated clear differences depending on genotype for instance leaves of Indonesian genotype was green, including leave neck, then again leaves of the American genotype was green shaded with green-red neck while the leaves of the Brazilian genotype was green with some reasonable red spots. The three genotypes likewise differentiated in branching capacity as the American genotype frame three branches while Indonesian and Brazilian genotypes have no branching capacity. The outer shade of the American tubers was light brown; then again outside tuber shade of Indonesian and Brazilian genotypes was dark brown. Concerning the interior shade of Brazilian genotype, tubers were pink, while the Indonesian tubers were light pink, yet American genotype was white. Tuber lengths likewise measured, and the American tubers were the tallest, then Brazilian tubers were taller than Indonesian which considered the briefest. Concerning tuber distance across, Brazilian tuber width gave the most elevated qualities, trailed by the American, while the Indonesian gave least values. American tubers weight was the biggest, followed by Brazilian, and Indonesian tubers weight was the least one.

Ten SSR primers successfully generated reproducible and reliable amplicons for the three imported cassava genotypes. Population structure was analysed by means of genetic distances and probabilistic models; allelic frequencies were used in order to assess the genetic diversity indexes ( $\mathrm{Ht}, \mathrm{Ho}, \mathrm{PIC}, \%$ polymorphism and a number of alleles) for each studied locus. Some microsatellite loci typed were polymorphic. The average number of alleles per locus was 2.700 ranging from 1 in SSRY38 and SSRY103 to 4 in SSRY108 and SSRY4. Mean observed heterozygosity was 0.02 ranging from 0.000 in SSRY106, SSRY38, SSRY103, SSRY177, GA-136 and GA-134 to 0.667 in SSRY108 and SSRY4 while the mean expected heterozygosity was 0.600 ranging from 0.000 in ssry38 and ssry103 to 0.800 in SSRY108, SSRY177, SSRY4, GA-136 and GA-134. The average PIC was 0.443 ranging from 0.000 at locus SSRY38 and SSRY103 to 0.620 at locus SSRY108 and SSRY4. Outcomes demonstrated that genetic similarity between the three cassava genotypes was running from $25 \%$ to $41.7 \%$, highest percentage 41.7 was between American and Brazilian genotypes. The lowest percentage of $25 \%$ was between American and Indonesian genotypes. Dendrogram exhibited a strong association between the American and Brazilian, on the other hand, this association was lower between the American and the Indonesian relationship, and these are because of the root of species sources.
\end{abstract}

Keywords: Cassava, Manihot Esculenta Crantz, Morphological diversity, Molecularly genetic diversity, SSR.

\section{Introduction}

Cassava (Manihot esculenta Crantz) has a place with the Euphorbiaceae family, it is a tropical root plant that started in South America and spread all through the world by Portuguese mariners in the sixteenth century. Bit by bit cassava has turned into a monetarily critical yield in creating nations. Cassava is a critical wellspring of sustenance for human utilization particularly in the American, African and Asian landmasses. Cassava is the third highest source of calories in the inter-tropical zone of the world [11]. Today cassava ranks fourth among the major sources of carbohydrates in the tropics; where it is an important food for over 500 million people $[10,19]$. Cassava has the advantage of being well adapted to a wide range of environmental stresses. It grows very well in the less fertile soil in contrast to many other crops that are highly vulnerable to environmental stresses during critical stages of plant development [35]. It is used as a subsidiary food and also as a raw material for the starch industry [32]. Studies have been conducted earlier to assess the variability based on biometrical characters as well as RAPD markers [23, 24]. DNA-based molecular markers such as RAPDs, RFLPs and microsatellites were used to develop the cassava molecular genetic map [12]. There is a wide range of molecular techniques available to assess genetic variability of a species. Due to their co-dominant inheritance, robustness and amenability to high throughput, simple sequence repeats (SSRs) or microsatellites have become a tool of choice for investigating important crop germplasm [14]. A considerable amount of genetic variation exists in cassava germplasm due to its heterozygous nature [30]. In cassava, SSR markers have been used to search for duplicates in the CIAT core collection [5] and to analyse variation in natural Comparison of old and new collection using SSR markers [22]. At present more than 500 SSR markers are available in cassava which will provide genetic tags for various phenotypes in cassava. Previous studies have 
reported the diversity/variability among the cultivars through morphological, biochemical [13, $33]$ and DNA markers [24, 25]. The present study exclusively depends on DNA analysis using SSR markers to elucidate the genetic diversity among three cassava genotype.

Objectives of the present study were to:

1. Quantify the genetic variability and diversity available in cassava genotypes in Egypt.

2. Statistically, analyse the data through clustering algorithm and principal component analysis.

3. Report degree of diversity and differentiation among cassava genotypes in Egypt, assessed using genomic SSR markers.

\section{Material and methods}

\subsection{Plant material}

Three cassava genotypes obtained from the Horticulture Research Institute (HRI). This study was carried out in the green house of the Genetics Department, Faculty of Agriculture Moshtohor, Benha Branch, Zagazig University and Laboratories.

\subsection{Root length}

Root length was recorded in centimetre utilizing a $50 \mathrm{~cm}$ ruler, tubers lengths were measured twice and after that the average computed.

\subsection{Root diameter}

Root diameter was recorded in centimetre by using a calliper. Tubers diameters were measured in pairs and then the average of each two replicates calculated.

\subsection{Weight of 10 tubers}

Ten tubers selected randomly from each replicate, these random samples have been weighted by using $30 \mathrm{~kg}$-balance. Average calculated for each replicate.

\subsection{Crop weight}

Tubers were taken completely for each replicate, Root weights were determined in gram using an electronic balance. Then obtained the quantity per hectare.

\subsection{Total protein of roots, and Leafs}

Sample processing

Samples dried inside the oven for 24 hours at a temperature of $70^{\circ} \mathrm{C}$ for 3 hours, dried samples completely crushed at kubba. Total protein was determined according to [1]

\subsection{Total carbohydrate of Root and leaf}

Sample processed as described previously and, total carbohydrates was determined as described by $[3,18]$.

\subsection{DNA extraction}

DNA was extracted using standard procedures according to [7] with slight modifications.

\subsection{Polymerase chain reaction (PCR)}

Polymerase chain reaction was carried out in a GeneAmp ${ }^{\circledR}$ PCR system 9700 thermal Cycler (Applied Bio systems, USA) using primers listed in Table (1).

Table (1) List of selected Microsatellite markers and their primers sequence

\begin{tabular}{|c|c|c|c|}
\hline NO & Microsatellite marker & Nucleotide sequence $5^{\prime} \rightarrow 3^{\prime}$ & $\mathbf{A T}$ \\
\hline 1 & SSRY 21 & $\begin{array}{c}\text { CAACAATTGGACTAAGCAGCA } \\
\text { CCTGCCACAATATTGAAATGG }\end{array}$ & 57 \\
\hline 2 & SSRY106 & $\begin{array}{l}\text { GGAAACTGCTTGCACAAAGA } \\
\text { CAGCAAGACCATCACCAGTTT }\end{array}$ & 57 \\
\hline 3 & GA-136 & $\begin{array}{c}\text { CGTTGATAAAGTGGAAAGAGCA } \\
\text { АсTCCACTCCCGATGCTCGC }\end{array}$ & 56 \\
\hline 4 & SSRY177 & $\begin{array}{l}\text { ACCACAAACATAGGCACGAG } \\
\text { CACCCAATTCACCAATTACCA }\end{array}$ & 45 \\
\hline 5 & SSRY59 & $\begin{array}{c}\text { GCAATGCAGTGAACCATCTTT } \\
\text { CGTTTGTCCTTTCTGATGTTC }\end{array}$ & 55 \\
\hline 6 & SSRY38 & $\begin{array}{c}\text { GGCTGTTCGTGATCCTTATTAAC } \\
\text { GTAGTTGAGAAAACTTTGCATGAG }\end{array}$ & 55 \\
\hline 7 & SSRY4 & $\begin{array}{l}\text { ATAGAGCAGAAGTGCAGGCG } \\
\text { CTAACGCACACGACTACGGA }\end{array}$ & 45 \\
\hline 8 & SSRY108 & $\begin{array}{c}\text { CATGCCACATAGTTCGTGCT } \\
\text { ACGCTATGATGTCCAAAGGC }\end{array}$ & 55 \\
\hline 9 & SSRY103 & $\begin{array}{l}\text { TGAGAAGGAAACTGCTTGCAC } \\
\text { CAGCAAGACCATCACCAGTTT }\end{array}$ & 55 \\
\hline 10 & GA-134 & $\begin{array}{c}\text { ACAATGTCCCAATTGGAGGA } \\
\text { ACCATGGATAGAGCTCACCG }\end{array}$ & 52 \\
\hline
\end{tabular}


PCR conditions include initial denaturation of 3 min at $95{ }^{\circ} \mathrm{C}$, followed by 35 cycles of 30 seconds at $95{ }^{\circ} \mathrm{C} ; 1 \mathrm{~min}$ at the annealing temperature defined for each primer Table (1), and $1 \mathrm{~min}$ at 72 ${ }^{\circ} \mathrm{C}$ The final extension included $30 \mathrm{~min}$ at $72{ }^{\circ} \mathrm{C}$ and final hold at $4^{\circ} \mathrm{C}$. The PCR products were checked for amplification on 1.5\% agarose gel. PCR products with high quality amplifications subjected to capillary electrophoresis with ABI 3730 DNA genetic analyzer for fragment segregation, and allele calls were made using GENEMAPPER software v.3.7 (Applied Biosystems).

\subsection{Data analysis}

The data generated by Gene Mapper were analyzed for genetic diversity parameters, including number of alleles per locus, allelic frequency, percent of polymorphic loci, observed heterozygosity, genetic differentiation and gene diversity (expected heterozygosity) obtained per locus, using Total lap and Curves 3.0.7 software Cluster analysis for the genotype was performed on the similarity matrix using NTSYS-pc and the results displayed as a dendrogram. Standard genetic distances among genotype computed using SPSS program.

\section{Result}

\subsection{Vegetative and fruiting qualities of three cassava genotypes}

Information represented in Table (2) and Fig (1, between various genotypes in every considered character. leaf colours exhibited clear differences relying upon genotype Table (2) and Fig (1) for example leaves of Indonesian genotype was green, including leave neck, on the other hand leaves of the American genotype was green with green-red neck while leaves of Brazilian genotype was green with some sensible red spots, and red neck.

With regard to stem branching data on Table (2) and Fig (2) indicated that no-branches detected in all varieties during young ages. In maturity ages The three genotypes separated in branching manner as the American genotype outline three branches while Indonesian and Brazilian genotypes have no branches on the main stem.

Table (2) and Fig (3) show the external color of the tubers. American tubers was light dark; while outside tuber shade of Indonesian and Brazilian genotypes was dull dark colored. Concerning the inside colour of Brazilian genotype, tubers were pink, while the Indonesian tubers were light pink, yet American genotype was white.

Tuber lengths similarly measured, and the American tubers were the tallest, at that point Brazilian tubers were taller than Indonesian which considered the shortest. With respect to thickness of the tuber, Brazilian tuber width gave the most lifted qualities, trailed by the American, while the Indonesian gave minimum esteems. American tubers weight was the greatest, trailed by Brazilian, and Indonesian tubers weight was the minimum one.

2 , and 3) uncovered morphological contrasts

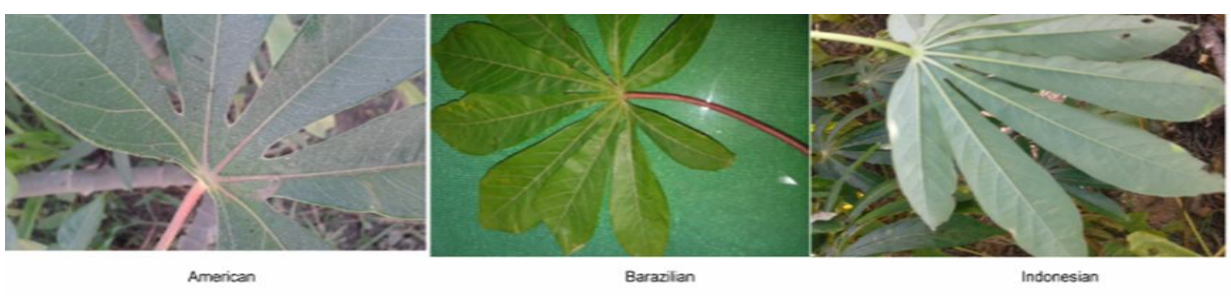

Fig (1) Leaf color for three genotypes of quinoa

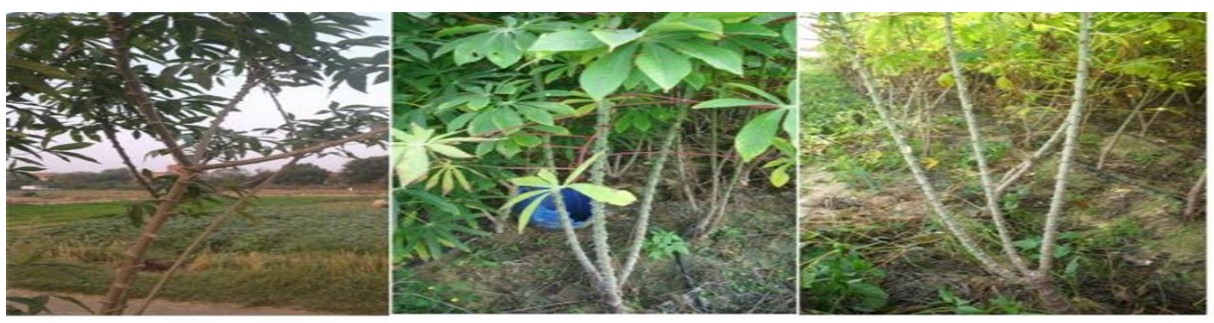

American

Barazilian

Indonisian

Fig (2) Stem branching of three varieties of quinoa
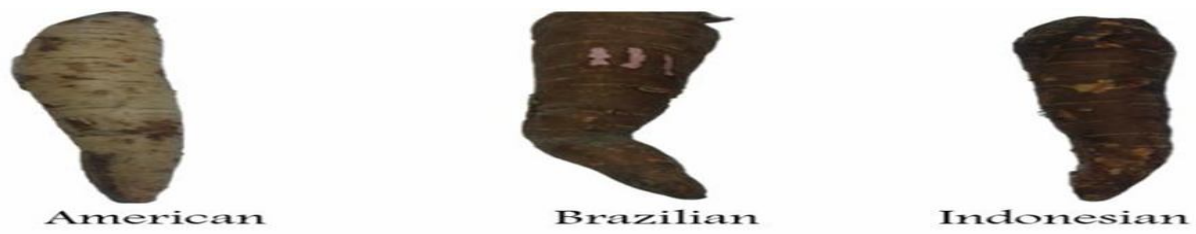

Fig (3) Tubers color for three genotypes of quinoa 
The same results were obtained for crop Tubers of hectare for each variety, Where he was variety the American (10.555 $\mathrm{t} / \mathrm{ha}$ ) is Larger than the other varieties in the crop of tubers followed by Brazilian (9.068 t/ha), While the Indonesian (7.980 t/ha) be smaller than the other varieties, While the
Indonesian be smaller than the other varieties. This results less than [28] Evaluated Six cassava varieties for tuber yield produced the highest marketable yield at $19.5 \mathrm{t} / \mathrm{ha}$, followed by 'Fine Leaf', of a similar growth habit, which yielded 16.7 $\mathrm{t} /$ ha of marketable tubers.

Table (2) Leaf Colour, Stem branching ability, tuber diameter, Root length, 10 tubers weight, yield / feddan and yield / per hectar as scored for the three genotypes

\begin{tabular}{lllccccc}
\hline Genotype & leaf Color & $\begin{array}{c}\text { stem } \\
\text { branching }\end{array}$ & $\begin{array}{c}\text { tuber } \\
\text { diameter }\end{array}$ & $\begin{array}{c}\text { root length in } \\
\text { Centimeter }\end{array}$ & $\begin{array}{l}\text { weight of } \\
\text { 10 tubers }\end{array}$ & $\begin{array}{c}\text { Yield } \\
\text { /feddan }\end{array}$ & $\begin{array}{l}\text { Yield / } \\
\text { hectar }\end{array}$ \\
\hline American & $\begin{array}{l}\text { Green with } \\
\text { green-red neck } \\
\text { Brazilian }\end{array}$ & $\begin{array}{l}\text { Three- } \\
\text { branches }\end{array}$ & 2.9 & 33 & $4.030 \mathrm{~kg}$ & $4.271 \mathrm{mt}$ & $10.555 \mathrm{mt}$ \\
$\begin{array}{l}\text { veins } \\
\text { Indonesian red } \\
\text { green, including } \\
\text { leave neck }\end{array}$ & $\begin{array}{l}\text { Non } \\
\text { branched }\end{array}$ & $\begin{array}{l}\text { Non } \\
\text { branched }\end{array}$ & 3.4 & 31 & $3.416 \mathrm{~kg}$ & $3.669 \mathrm{mt}$ & $9.068 \mathrm{mt}$ \\
\hline
\end{tabular}

\subsection{Chemical composition of some varieties of} cassava

It is clearly evident from Cassava vital plants that contain a certain amount of carbohydrates, protein, and is determined on the basis of the nutritional value of plant leaf.

\subsection{The total carbohydrates in the leaves and tubers}

The total carbohydrates in the leaves of American genotype was $(7.35 \%)$ are greater than the other two genotypes. Indonesian total carbohydrate
$(5.24 \%)$ recorded lowest value at all. On the other hand tubers content of carbohydrates in Brazilian $(42.04 \%)$ is greater than the other varieties, while the Indonesian total carbohydrate $(39.36 \%)$ was the lowest Table (3). This result agree with [28] as he evaluated six cassava varieties for tuber yield found that the cassava varieties were very high in carbohydrates, averaging $31.9 \%$ of dry matter. [9] Developed a number of varieties for their nutritional properties found that carbohydrate $(83.42-87.35 \%)$

Table (3) Chemical composition of some varieties of cassava

\begin{tabular}{lcc}
\hline Cultivars & Total carbohydrates in the leaves & Total carbohydrates in the Tubers \\
\hline American & 7.35 & 41.81 \\
Brazilian & 5.555 & 42.04 \\
Indonesian & 5.235 & 39.36
\end{tabular}

\subsection{The total Protein in the leaves and tubers}

It is clearly evident from Table (4) that the leaves content of Protein was greater in Indonesian cassava $(28.22 \%)$, but the Brazilian cassava gave only $(20.32 \%)$ total Protein which concedered the lowest value. Tubers content of Protein in Indonesian $(3.51 \%)$ is greater than the other varieties, the Brazilian total Protein $(2.72 \%)$ lower than the other two genotypes. These results agree with [28] Evaluated Six cassava varieties for tuber y protein contents for all varieties were very low, ranging from $1.2 \%$ to $2.1 \%$. [9] Found that protein in tubers ranged between $1.17-3.48 \%$ to number of varieties. [4] Revealed that Carotenoid-Protein content in cassava storage root (CSR) is low but variable. [8] Concluded that a chemical and biological evaluation of the protein content of some leaves of cassava (Munihot utilissima). The protein content of the leaves was from 30 to $40 \%$ (expressed as percentage of leaf dry matter). The concentrations of essential amino acids were adequate, except for methionine. [36] Found that the highest levels of crude protein in leaves number of cassava cultivars adapted to many different regions.

Table (4) Chemical composition of some varieties of cassava

\begin{tabular}{lcc}
\hline Cultivars & Total Protein in the leaves & Total Protein in the Tubers \\
\hline American & 24.355 & 3.29 \\
Brazilian & 20.320 & 2.72 \\
Indonesian & 28.215 & 3.51 \\
\hline
\end{tabular}

\subsection{Simple sequence repeats markers (SSR)}

Genetic diversity parameters were assessed to10 SSR markers, with three cassava genotypes (American, Brazilian, and Indonesian) and the results are presented in Table (5), A total of 27 polymorphic alleles to the three cassava genotypes.
The number of alleles across loci ranged between 1 and 4 with average number of alleles of 2.7 SSRY108, SSRY4 recorded the highest number of alleles and SSRY38, and SSRY103 recorded the lower number of alleles Table (5). Of the 27 alleles revealed by 10 SSR markers across loci, 20 (74\%) 
were unique alleles. The SSRY108, SSRY103, SSRY177, SSRY4, GA-136 and GA-134 recorded the highest number (2) of unique alleles. The average expected heterozygosity (gene diversity) (He) averaged from 0.000 in SSRY 38,SSRY103 to 0.800 in SSRY108, SSRY177, SSRY4, GA-136, GA-134 with an average of 0.600, while observed heterozygosity ranged from 0.000 in SSRY106, SSRY38, SSRY103, SSRY177, GA-136 and GA134 to 0.667 in SSRY108 and SSRY4, respectively, with an average of 0.2 . Polymorphic information content (PIC) of loci was highest in SSRY 108,SSRY4 (0.620) and lowest in SSRY106 (0.346) with average of 0.443 Table (6).

Table (5) Genetic diversity parameters averaged across all loci

\begin{tabular}{lcccccc}
\hline Locus & $\begin{array}{c}\text { No of } \\
\text { alleles }\end{array}$ & $\begin{array}{c}\text { No of unique } \\
\text { alleles }\end{array}$ & $\begin{array}{c}\text { \% alleles } \\
\text { unique }\end{array}$ & HObs & HExo & PIC \\
\hline SSRY21 & 3 & 2 & 0.666 & 0.333 & 0.733 & 0.535 \\
SSRY106 & 2 & 1 & 0.500 & 0.000 & 0.533 & 0.346 \\
SSRY59 & 3 & 2 & 0.666 & 0.333 & 0.733 & 0.535 \\
SSRY38 & 1 & 0 & 0.000 & 0.000 & 0.000 & 0.000 \\
SSRY108 & 4 & 3 & 0.750 & 0.667 & 0.800 & 0.620 \\
SSRY103 & 1 & 0 & 0 & 0.000 & 0.000 & 0.000 \\
SSRY177 & 3 & 3 & 1.000 & 0.000 & 0.800 & 0.593 \\
SSRY4 & 4 & 3 & 0.750 & 0.667 & 0.800 & 0.620 \\
GA-136 & 3 & 3 & 1.000 & 0.000 & 0.800 & 0.593 \\
GA-134 & 3 & 3 & 1.000 & 0.000 & 0.800 & 0.593 \\
& 27 & & & & & \\
\hline
\end{tabular}

${ }^{*} \mathrm{He}=$ expected heterozygosity (gene diversity), Ho = observed heterozygosity, Unique alleles = Alleles only in landraces, $\mathrm{PIC}=$ Polymorphic Information Content

Similarity indices table (6) among the three cassava varieties based on SSR analysis revealed that the highest value was between American cassava and Brazilian cassava $(41.7 \%)$. followed $(25.0 \%)$ by Brazilian Cassava and Indonesian and also between American and Indonesian Table (6).

Table (6) Similarity indices among the three cassava genotypes based on SSR analysis

\begin{tabular}{lccc}
\hline & American & Brazilian & Indonesian \\
\hline American & 100 & & \\
Brazilian & 41.7 & 100 & 100 \\
Indonesian & 25 & 25 & \\
\hline
\end{tabular}

The dendrogram was constructed using the Neighbor Joining Method (NJ) (Nei, 1973) and separated the three of genotype into two clusters $\operatorname{Fig}(5)$.
American Cassava and Brazilian Cassava were included in cluster 1 . The clusters 2 contained Indonesian Cassava only. The dendrogram showed strong relationship between American and Brazilian.

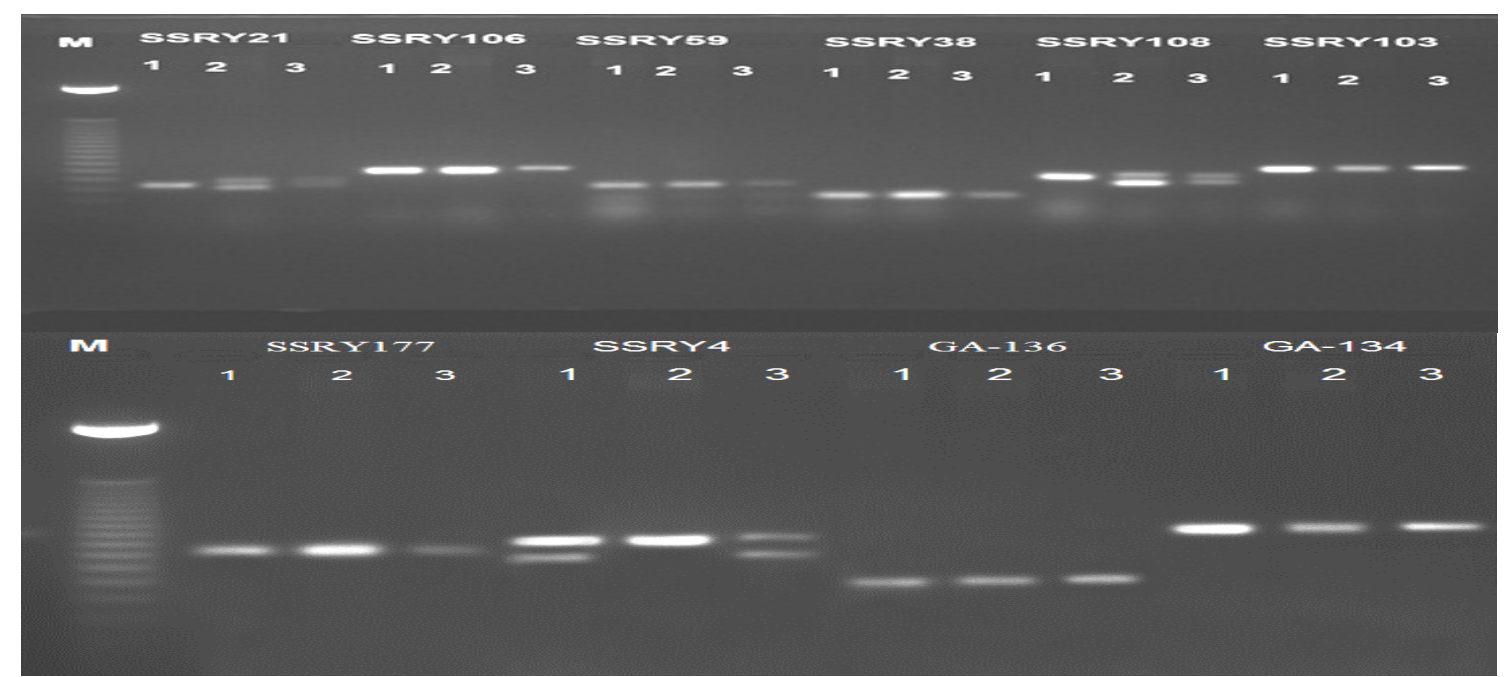

Fig (4) Representative gels showing SSR marker with three Cassava Genotype $(1$ = American, $2=$ Brazilian, 3 = Indonesia 

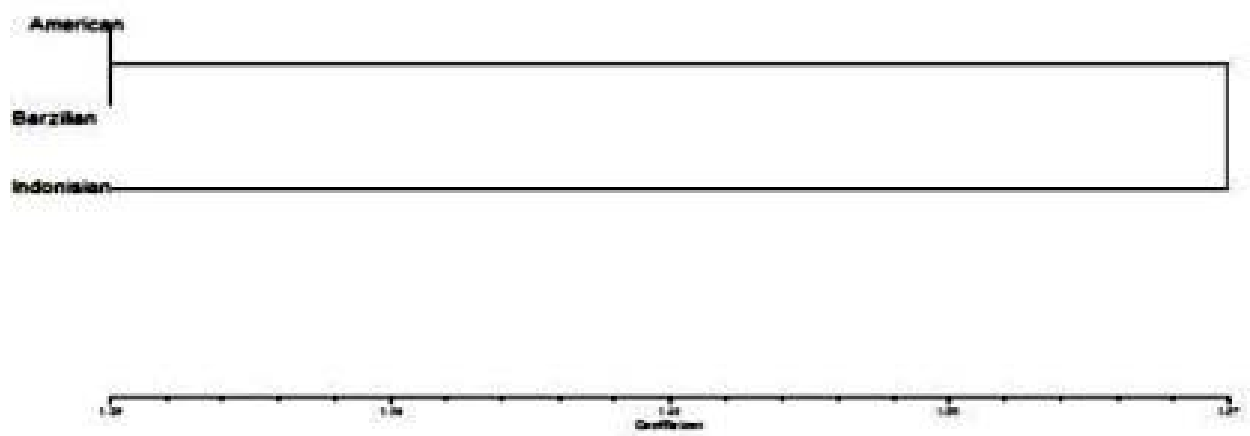

Fig (5) Dendrogram of the three cassava genotype (Manihot esculenta) obtained from 10 microsatellite markers polymorphism using the similarity index of Jaccard, bootstrap values and the un-weighted pair group method with arithmetic mean (UPGMA).

\section{Discussion}

Number of polymorphic alleles were agree with [27] a total of 26 alleles with 2-4 alleles per loci were generated 93 cassava accessions with 14 microsatellite primers and( Siqueira et al. ( 2011) an average, 3.4 alleles per locus were generated 20 cassava genotypes with nine microsatellite primers and higher than [15] Each primer yielded 1 to 2 amplicon were generated from Thirty six ssr primers with 45 accessions and lower than less than While It less than [2] A total of 47 alleles were detected. The number of alleles varied from a range of three to nine from 37 cassava cultivars with nine microsatellite markers, and [21] A total of 131 alleles with an average of 3.7 alleles per loci were found were generated six cassava with 36 SSR markers and [34] an average of seven (7) alleles per locus use of 36 simple sequence repeats (SSRs) to produce SSR allelic polymorphisms for estimation of inter- and intra-population genetic diversity among Ghanaian cassava cultivars from five Ghanaian released and local cassava populations consisting of 11 released and two local cultivars. This level of polymorphism in the alleles of ssr markers confirms that genetic diversity to cassava genotype can be useful for breeding programs. The number of allele Influenced by The number of primers, whenever the number of primers is high the number of allele is high.

The SSR markers showed mean PIC (44.35\%) demonstrating their ability to discriminate between Cassava genotype. PIC Estimate ranged between 0.000 in SSRY38, SSRY103 to 0.620 in SSRY108, SSRY4. These result less than [2] who Evaluated 37 cassava cultivars with nine microsatellite markers were the average value of the mean PIC was 0.60 [6] The polymorphic information content (PIC) values showed considerable genetic diversity with a mean value of 0.5076 and peak of 0.5707 for locus GA140.

[20] Studied 36 cassava genotypes with 16 SSR primers For the genotype identification study, the 16 SSR primers were screened by their polymorphic information content (PIC) values. Five SSR primers that have
PIC values between 0.50 and 0.67 were selected and further assessed using simple arithmetic progression combination method. because of the limited number of varieties.

The SSR markers showed the observed heterozygosity were lower than the expected heterozygosity where mean observed heterozygosity $(0.200)$ an expected heterozygosity (0.600) this result agree with [27] The average values for observed and expected heterozygosity were 0.18 and 0.46 , respectively from 93 cassava accessions with 14 microsatellite primers. [31] who assess the genetic diversity of 20 cassava genotypes with nine microsatellite primers.

The highest value was between American Cassava and Brazilian Cassava (41.7\%) . followed (25.0\%) by Brazilian Cassava and Indonesian and also between American and Indonesian. this result agree with [15]. the similarity between different accessions was estimated using the software package NTSYS-pc (Numerical Taxonomy Multivariate Analysis System). [16] The similarity index among the varieties varied from $65 \%$ to $98 \%$. The similarity coefficients generated between released varieties and central Kerala varieties ranged from 40 to $95 \%$ and two separate DNA cluster groups were formed at 0.60 coefficients using "numerical taxonomy" and "multivariate analysis system software package". The similarity index for released varieties ranged from 60 to $93 \%$ and in the case of central Kerala varieties it ranged from 70 to $98 \%$. [17] In both methods no cassava duplicate was identified, though the most morphologically closely related cassava landraces were Sindani and Ndingiwaka with similarity coefficient of 0.91 . [20] the similarity coefficients generated between improved cultivars and Nigerian landraces ranged from 0.42 to 0.84 , and 12 distinct DNA cluster groups were identified at 0.70 coefficients using Numerical Taxonomy and Multivariate Analysis System software package. [21] Reported that six cassava cultivars using 36 SSR markers, Jaccard's distance similarly coefficient indicated that the relative genetic 
distance between cultivars is high, ranging from 0.548 to 0.771 . [27] Estimate the genetic similarity among 93 cassava accessions with 14 microsatellite primers. The genetic similarity ranged from 0.16 to 0.96 . The average values for observed and expected heterozygosity were 0.18 and 0.46 , respectively.

The genetic relationships among the studied three Cassavas genotype showed that there were two separate clusters. It less than [20] Studied Thirty-one improved cultivars and five Nigerian landraces of cassava were assessed at genomic DNA level with 16 SSR primers for genetic diversity study. Five SSR primers that have PIC values between 0.50 and 0.67 were selected and further assessed using simple arithmetic progression combination method. The results obtained revealed a combination of these 5 primers from SSR primers collection at IITA that could readily distinguish the 36 cassava genotypes at 0.93 similarity coefficient. These five primers clustered the 36 cassavas into 16 groups at 0.70 similarity coefficient. [21] Reported that six cassava cultivars using 36 SSR markers, One yellow-fleshed root cultivar clustered with a white cultivar, indicating a close genetic relationship. where the genotype is low.

\section{Reference}

[1] AOAC. Official Methods of Analysis of the Association of Official Analytical Chemistry. 16th Edn., AOAC International, Washington, USA., p.1141, 1995.

[2] E.Aragon, V.Aguilar and J.Arguello. Genetic diversity of Manihot esculenta Crantz cultivars in Nicaragua assessed with microsatellite (SSR). Biotecnología Vegetal vol.12(4), pp.211-219, 2012.

[3] Peter Bernfeld. Methods in enzymology. by SP Colowick and NO Kaplan, Academic Press Inc., New York, pp.149, 1955.

[4] L.J.C.B.Carvalho, J.D.De Almeida, J.V.Anderson, E.A.Vieira, S.Chen, CR Batista de Souza, E. Fuhrmann and J.Padilha da Silva. Studies on variation of carotenoid-proteins content in Cassava (Manihot esculenta Crantz) storage root reveal implications for breeding and the use of induced mutations. Embrapa Recursos Genéticos e Biotecnologia-Artigo em periódico indexado (ALICE) 2013.

[5] Paul Chavarriaga-Aguirre, María M.Maya, Joe Tohme, Myriam C.Duque, Carlos Iglesias, Merideth W.Bonierbale, Steve Kresovich and Gary Kochert. Using microsatellites, isozymes and AFLPs to evaluate genetic diversity and redundancy in the cassava core collection and to assess the usefulness of DNA-based markers to maintain germplasm collections. Molecular Breeding vol.5(3), pp.263-273, 1999.

[6] T.R.da Costa, P.S.Vidigal Filho, M.C.Gonçalves-Vidigal, M.Z.Galván,
G.F.Lacanallo, L.I.da Silva, and M.V.Kvitschal. Genetic diversity and population structure of sweet cassava using simple sequence repeat (SSR) molecular markers. African Journal of Biotechnology, vol.12(10), 2013.

[7] S.L.Dellaporta, J.Word and J.B.Hicks. A plant DNA preparation, Plant Molecular Biology vol.4, pp.19-21, 1983.

[8] B.O.Eggum. The protein quality of cassava leaves. British Journal of Nutrition, vol.24(3), pp.761-768, 1970.

[9] O.A.Emmanuel, A.Clement, S.B.Agnes, L.Chiwona-Karltun and B.N.Drinah. Chemical composition and cyanogenic potential of traditional and high yielding CMD resistant cassava (Manihot esculenta Crantz) varieties. International Food Research Journal vol.19(1), pp.175-181, 2012.

[10] FAO, FAOSTAT Statistical Databases of Food and Agriculture Organization Rome, Italy, 2001.

[11] FAO, Statistic system of Food and Agriculture Organization of the United Nations, 2010. Available in: $<$ http://faostat.fao.org/site/567/default.aspx\#anc or $>$. Acess in: February 16.

[12] M.Fregene, Fernando Angel, Rocío Gómez, Fernando Rodríguez, P.Chavarriaga, W.Roca, J.Tohme and M.Bonierbale. A molecular genetic map of cassava (Manihot esculenta Crantz). Theoretical and Applied Genetics vol.95(3), pp.431-441, 1997.

[13] P.Harisankar, Santha V.Pillai, G.O.Sumarani and S.Sundaresan. Isozyme analysis of cassava germplasm: Identification of duplicates in exotic collection. Plant Cell Biotechnology and Molecular Biology, 2002.

[14] Sc.Hokanson, A.K.Szewe-McFadden, W.F.Lamboy and J.R.Mc-Ferson, Microsatellite (SSR) markers reveal genetic identities, genetic diversity and relationships in a Malusx domestica Borkh, core subset collection, Theoretical and Applied Genetics vol.97, pp.671-683, 1998.

[15] S.S.Lekha, Santha V.Pillai and J.Sree Kumar. Molecular genotyping of Indian cassava cultivars using SSR markers. Adv. Environ. Biol. Vol.4(2), pp.224-233, 2010.

[16] S.S.Lekha, J.A.T.Silva and S.V.Pillai. Genetic variability studies between released varieties of cassava and central Kerala cassava collections using SSR markers. Journal of Stored Products and Postharvest Research, vol.2(4), pp.79-92, 2011.

[17] L.D.Lyimo, F.M.Tairo and C.L.Rweyemamu. Morphological and molecular characterization of Cassava (Manihot esculenta Crantz) landraces using SSR markers." Int. J. Int. Biol. Vol.2, pp.71-78, 2012. 
[18] G.L.Miller, Use of dinitrosalicylic acid reagent for determination of reducing sugars. Analytical Chemistry, vol.31, pp.426-428, 1959.

[19]J.A.Montagnac, C.R.Davis and S.A.Tanumihardio. Nutritional value of cassava for use as a staple food and recent advances for improvement, Comprehensive Review in Food Science and Food Safety vol.8, pp.181-194, 2009.

[20] O.Moyib, O.A.Kodunola and A.G.O.Dixon. SSR markers reveal genetic variation between improved cassava cultivars and landraces within a collection of Nigerian cassava germplasm. African Journal of Biotechnology vol.6(23), pp.2666-2674, 2007.

[21]D.N.C.Njoku, N.Egesi, E.Okogbenin, E.V.Gracen, I.Asante and S.Offei. Assessment of genetic diversity in cassava based on SSR markers and morphological characters. Journal of Sustainable Agriculture and the Environment. Vol.14 (1/2), pp.1-16. 2013.

[22] K.M.Olsen and B.Schaal. Microsatellite variation in cassava (Manihot esculenta), Euphorbiaceae and its wild relatives: evidence for a southern Amazonian origin of domestication, American Journal of Botany vol.88, pp.131-142, 2001.

[23] S.V.Pillai.Variability and genetic diversity in cassava, Indian Journal of Genetics vol.62, pp.242-244, 2002.

[24] S.V.Pillai, S.P.Manjusha and S.Sundaresan. Molecular diversity in the land races of cassava in India based on RAPD markers. Paper presented in the Sixth International Scientific meeting of the Cassava Biotechnology Network. CIAT, Cali,Colombia, March 8-14, p.45, 2004.

[25] S.V.Pillai and V.Sreelekha. Molecular variability in 45 Indian taro cultivars, The Asian and Australasian journal of plant science and biotechnology vol.2(2), pp.102-106, 2008.

[26]A.A.J.Raji, I.Fawole, M.Gedil and A.G.O.Dixon. Genetic differentiation analysis of African cassava (Manihot esculenta) landraces and elite germplasm using amplified fragment length polymorphism and simple sequence repeat markers. Annals of Applied Biology, vol.155, pp.187-199, 2009.
[27]M.D.N.O.Ribeiro,

S.P.D.Carvalho,

J.B.D.Santos and R.P.Antonio. Genetic variability among cassava accessions based on SSR markers. Crop Breeding and Applied Biotechnology, vol.11(3), pp.263-269, 2011.

[28] K.V.A.Richardson. Quality characteristics, root yield and nutrient composition of six Cassava (Manihot esculenta Crantz) varieties. gladstone road agricultural centre crops research report no. 18, 2013.

[29] D.J.Rogers. Studies on M. esculenta Crantz (cassava) and related species. Bulletin of the Torrey Botanical Club, vol.90, pp.43-54, 1963.

[30]M.V.B.M.Siquera, J.R.Queiroz-Silva, E.A.Bressan, A.Borges, K.J.C.Pereira, J.G.Pinto and E.A.Veasey. Genetic characterization of cassava (Manihot esculenta) landraces in Brazil assesses with simple sequence repeats, Genetics and Molecular Biology vol.32, pp.104-110, 2009.

[31] M.V.B.M.Siqueira, A.Borges, T.L.Valle and E.A.Veasey. A comparative genetic diversity assessment of industrial and household Brazilian cassava varieties using SSR markers. Bragantia, vol.70(4), pp.745-752, 2011.

[32] T.Srinivas. Industrial demand for cassava starch in India. Sarch/Staerke vol.59(10), pp.477-481, 2007.

[33] G.O.Sumarani, S.V.Pillai, P.Harisankar and S.Sundaresan. Isozyme analysis of indigenous cassava germplasm for identification of duplicates, Genetic Resources and Crop Evolution vol.51, pp.205-209, 2004.

[34] P.Twumasi, E.W.Acquah, M.D.Quain and E.Y.Parkes. Use of simple sequence repeat (SSR) markers to establish genetic relationships among cassava cultivars released by different research groups in Ghanaian. International Journal of Genetics and Molecular Biology, vol.6(3), pp.29-36, 2014.

[35] N.Ugorji. Genetic characterization of cassava cultivars in Nigeria: Morphological and molecular markers. MSc Dissertation, University of Ibadan, Ibadan, Nigeria, 1998.

[36]C.Wobeto, A.D.Correa, C.M.P.Abreu, C.D.Santos and J.R.Abreu, nutrients in the Cassava (Manihot esculenta Crantz) leaf meal at three ages of the plant1. Cienc. Tecnol. Aliment., Campinas, vol.26(4), pp.865-869, 2006. 